\title{
The Effects of Family Structure and Parenthood on the Academic Performance of Nigerian University Students
}

\author{
V.O.Uwaifo \\ Department of Vocational and Technical Education, Ambrose Alli University, \\ Ekpoma, Edo State, Nigeria \\ Telephone: (234) 08035472684, E-mail: vuwaifo@yahoo.com
}

KEYWORDS Parent Education. Academic Performance. Family Structures

\begin{abstract}
This paper examines the effects of family structure and parenthood on the academic performance of Nigerian university students. The sample for the study consisted of 240 students drawn from the six randomly selected faculties in Ambrose Alli University, Ekpoma, Edo State. The adapted form of "Guidance and Counseling Achievement Grade Form" was used for data collection and the data collected were subjected to statistical analysis using the t-test statistical method. The three null hypotheses formulated were tested at .05 level of significance. The results showed that significant differences existed between the academic performance of students from singleparent family and those from two-parent family structures. The results also indicated significant differences in academic performance of male and female students compared on two types of family structures. On the basis of these findings, it was recommended that school counsellors should be employed in all schools and that they should provide necessary assistance to students especially those from single-parent family to enable them overcome their emotional concerns.
\end{abstract}

\section{INTRODUCTION}

Over the years, the investigations of the factors that influence academic performance of students have attracted the interest and concern of teachers, counselors, psychologists, researchers and school administrators in Nigeria (Wiseman 1973; Sogbetun 1981). This is because of the public outcries concerning the low standard of education in the country (Imoge 2002). The declining quality of education in the country and the breeding of graduates with little technical know-how has resulted in serious set backs to the industrial development of the nation. Different factors are capable of influencing the academic performance of university students. Such factors may be the student's internal state (intelligence, state of health, motivation, anxiety etc.) and their environment (availability of suitable learning environment, adequacy of educational infrastructure like textbooks and well-equipped laboratories).

Investigation of these factors has produced several findings by researchers. For example, Clemens and Oelke (1967) and Emeke (1984) have attributed the cause of poor academic performance to a combination of personal and institutional factors. Personal factors relate to the individual's intelligence, knowledge and ability. While institutional factors are family or parental influences, societal influences, institutional in- fluences and school related factors- student/lecturer rapport, teacher related factors, accommodation and living conditions. In the same vein, Wiseman (1973), Sogbetan (1981) and Hassan (1983) among others have examined the causes of poor academic performance among secondary school students. Some of the factors identified are intellectual ability, poor study habit, achievement motivation, lack of vocational goals, low self-concept, low socio-economic status of the family, poor family structure and anxiety. The consequences of these include indiscipline in schools and low level of educational standard.

A Daily Sketch Publication on "Causes and Cures of Poor Performance at West African School Certificate Examination (WASCE)" in 2006 identified and categorized problems responsible for students' poor performance to problems of teachers, problems of inadequate facilities in the schools, problem traceable to students, problems caused by parents and society at large and problems of government policies and low funding of the education sector (Ajila and Olutola 2007).

Reviewed literature indicated that there is an awareness of the importance of the home environment or family on pupil's/student's academic performance. The home has a great influence on the students' psychological, emotional, social and economic state. In the view of Ajila and Olutola (2007), the state of the home affects the individual since the parents are the first socializing 
agents in an individual's life. This is because the family background and context of a child affect his reaction to life situations and his level of performance. Although, the school is responsible for the experiences that make up the individual's life during school periods, yet parents and the individual's experiences at home play tremendous roles in building the personality of the child and making the child what he is. Thus, Ichado (1998) concluded that the environment in which the student comes from can greatly influence his performance at school.

Although, the home environment or family has been recognized as having a lot of influence on the academic performance of students (Nzewuawah 1995); Ajila and Olutola 2007). Previous studies have been concentrated on the area of socio-economic status of parents. Other aspects of parental environment such as the structure of the family have been grossly neglected. Yet, Ichado (1998) stated that parent's constant disagreement affects children emotionally and this could lead to poor academic performance in school.

The family lays the psychosocial, moral and spiritual foundations in the overall development of the child. While the" mother's significant role in this cannot be over-emphasized. Studies on father-child relationship suggest that the presence of a father in the home influences significantly the development of a child (Agulanna 1999). Thus, parenthood is a responsibility requiring the full cooperation of both parents who must ensure the total development of their offspring(s).

Structurally, a family is either broken or intact. A broken family in this context is one that is not structurally intact for various reasons; death of a parent, divorce, separation, dissertation and illegitimacy in which case, the family was never completed (Conkline 1996). This analysis becomes necessary because life in a single parent family can be stressful for both the child and the parent. Such families are faced with the challenges of diminished financial resources (Children's Defence Fund 1994), assumptions of new roles and responsibilities, establishment of new patterns in intra-familial interaction and reorganization of routines and schedules (Agulanna 1999). These conditions are not conducive for effective parenting. This is because when the single parent is overburdened by responsibilities and by their own emotional reaction to their situa- tion, they often become irritable, impatient and insensitive to their children's needs (Nzewunwah 1995). It is against this general background that this study was conceived to investigate the possible contribution(s) of family structure to the academic performance of students of Ambrose Alli University, Ekpoma, Edo State.

\section{Hypotheses}

In pursuit of the research problems and to realize the objective of this study, the following hypotheses were raised and tested:

1) There is no significant difference between the academic performance of students from single parent families and those from two parent families.

2) There is no significant difference between the academic performance of male students from single parent families and male students from two parent families.

3) There is no significant difference between the academic performance of female students from single-parent families and female students from two-parent families.

\section{METHODOLOGY}

The population for this study consists of all university students in Nigeria. However, the sample for the study was drawn from the student population of Ambrose Alli University, Ekpoma, Edo State.

The sample was actually drawn using the students' record at the University Counseling Center. Six faculties were randomly selected from the total number of faculties within the university. From each of the six faculties - Law, Natural Sciences, Education, Arts, Basic Medical Sciences, Social Sciences - 40 students were purposefully selected. The selection from each faculty was based on equal number of students (20) from single-parent family and (20) from two-parent family. This made a total of 240 students that participated in the study. They were 120 students from single-parent family and 120 from two-parent family.

The instrument used to obtain relevant data was an adapted form of the "Guidance and Counseling Achievement Grade Form (GCAGF)". This instrument was basically used to collect data on the subjects' academic performance as measured by their scores in the compulsory courses taken 
in the previous semester in their various faculties. However, the first part of the form seeks information on the subjects' sex, and course of study. Four experts in the field of education validated the instrument and a reliability coefficient (0.67) was obtained through a test retest form of reliability.

The researcher personally went to each of the faculties to request for the scores of the participants in the compulsory courses taken in their various faculties. However, the subjects that were involved in this study were informed and the purpose of the study was clearly explained to them. They were assured of the confidential nature of the results of the study.

The t-test statistical method was used to analyze the collected data and the hypotheses formulated.

\section{RESULTS}

The results are presented as they relate to the hypotheses.

Hypothesis 1: There is no significant difference in the academic performance of students from single parent family and those from twoparent family.

The data in Table 1, indicates that there is a significant difference between the academic performance of students from single-parent family and those from two-parent family. The calculated t-value (4.66) is greater than the critical t-value (1.96) at 0.05 significance level and 238 degrees of freedom. Thus, the null hypothesis is therefore rejected.

Hypothesis 2: There is no significant difference between the academic performances of male students from two-parent family and male students from single-parent family.

Table 2, shows that there is a significant difference in the academic performance of male student from single parent family and male students

Table 1: $t$-test of difference in the academic performance of students from single-parent family and those from two-parent family.

\begin{tabular}{lcccccc}
\hline Types of home & $N$ & $X$ & S.D. & Df & $\begin{array}{c}t- \\
\text { cal }\end{array}$ & $\begin{array}{c}t- \\
t a b\end{array}$ \\
\hline $\begin{array}{l}\text { Single-parent } \\
\text { family }\end{array}$ & 120 & 49.64 & 4.92 & & & \\
$\begin{array}{l}\text { Two-parent } \\
\text { family }\end{array}$ & 120 & 57.51 & 5.68 & 238 & 4.66 & 1.96 \\
\hline
\end{tabular}

*Significant at $\mathrm{P}<.05$
Table 2: Difference between the academic performance of male students from two-parent family and male students from single-parent family.

\begin{tabular}{lcccccc}
\hline Types of home & $N$ & $X$ & S.D. & Df & $\begin{array}{c}t- \\
\text { cal }\end{array}$ & $\begin{array}{c}t- \\
\text { tab }\end{array}$ \\
\hline $\begin{array}{l}\text { Two-parent } \\
\text { family }\end{array}$ & 62 & 8.77 & 12.86 & & & \\
$\begin{array}{c}\text { Single-parent } \\
\text { family }\end{array}$ & 58 & 6.54 & 7.08 & 118 & 2.35 & 1.96 \\
\hline
\end{tabular}

*Significant at $\mathrm{P}<.05$

from two-parent family. The calculated $t$ value (2.35) is greater than the critical t-value (1.96) at 0.05 significance level and 118 degrees of freedom. Hence, the null hypothesis is rejected.

Hypothesis 3: There is no significant difference between the academic performances of female studentsfrom single-parent family and female students from two-parent family.

Table 3 shows that there is a significant difference between the academic performance of female students from two parent family and female students from single parent family. The calculated t-value (2.43) is greater than the critical tvalue (1.96) at 0.05 level of significance and 118 degrees of freedom. Thus, the null hypothesis is also rejected.

Table 3: Difference between the academic performance of female students from single-parent family and female students from two-parent family.

\begin{tabular}{lcccccc}
\hline Types of home & $N$ & $X$ & S.D. & Df & $\begin{array}{c}t- \\
\text { cal }\end{array}$ & $\begin{array}{c}t- \\
t a b\end{array}$ \\
\hline $\begin{array}{l}\text { Two- parent } \\
\text { Family }\end{array}$ & 62 & 62.47 & 10.37 & & & \\
$\begin{array}{l}\text { Single-parent } \\
\text { Family }\end{array}$ & 58 & 78.45 & 7.99 & 118 & 2.43 & 1.96 \\
\hline
\end{tabular}

*Significant at $\mathrm{P}<.05$

\section{DISCUSSION}

The results of this study indicate that there is a significant difference between the academic performance of students from single parent family and students from two-parent family. The study also shows differences in the performance of male students from the two family structures and also female students from the two family structures. The findings agreed with the conclusion of Nzewunwah (1995) that there is a significant difference between students from singleparent families and those from two-parent families in terms of attitude to examination malpractices, attitude to studies and academic performance. This finding could be explained by the 
fact that life in a single-parent family can be traumatic and children brought up in such family structure often suffer some emotional problems such as lack of warmth, love and disciplinary problems, which may hinder their academic performance. On the other hand, children raised in two-parent family structure are often stable emotionally and they suffer less emotional problems thereby making them less anxious in the pursuit of their academic work.

However, it should be noted that this situation might not be true all the time since there are some children in single parent family structures who still perform academically better than children from two parent family structure (Apia and Olutola 2007). This situation may however be attributed to other factors inherent in the personality of the child. Whatever the result, parental separation tends to affect younger children more than the adolescents who are the subject of this study. However, early childhood problem may have negative impact on later life development. It should also be mentioned here that the presence of other adults in a single parent household might bring some positive influences on the degree of tension that may be suffered by children from such background. Also, the cultural practice in Africa, which allows support for widows, widowers and other categories of single parents, helps to reduce the inconsiderable terms, the negative effect of single parenthood. In a Nigerian single parent family, some of the functions of the absent parent may be sufficiently taken over by the members of the extended family, friends and neighbours.

\section{RECOMMENDATIONS}

Based on the findings of the study, the following recommendations have been made:

Governments, private organizations and individuals concerned with the business of education should endeavor to address the obstacles hindering effective academic performance of students. This can be done by developing achievement motivation in students through achievement motivation training.

There is the need for the recognition of individual differences in students and the need to deal with them accordingly. Counselors should provide the necessary assistance and psycho- logical support for students from single parent family so as to overcome their emotional problems.

There is also the need to keep enlightening the parents of the importance of the home structure on the life of children. This is necessary so that parents can understand the implications and consequences of parental separation and thus mobilize all resources to curtail the problems arising from the situation.

Generally, there is need to combat the continuing declining state of education by providing more funds and materials for the upliftment of our educational system.

Finally, school counselors should be employed in institutions of learning and adequate supervision to be put in place to ensure provision of necessary guidance services to students.

\section{REFERENCES}

Agulanna GG 1999. Family structure and prevalence of behavioral problems among Nigerian adolescents. The Counselor, 17(1): 154-154.

Ajila C, Olutola A 2007. Impact of parents' socio-economic status on university students' Academic performance. Ife Journal of Educational Studies, 7(1): $31: 39$.

Clemens HM, Oelke MO 1967. Factors related to reported problems of adolescents, New York,. Personnel and Guidance Journal, 45: 699-702.

Coukline J 1996. Introduction to Criminology. New York: Macmillan.

Emeke EA1984. Relationship between personal problems and study habits. Journals of Applied Psychology, 3: 113-129.

Hassan T 1983. Psychosocial predictors of academic achievement. Psychology for Everyday Living, 2(2): 155: 169 (1983).

Ichado SM 1998. Impact of broken home on academic performance of secondary school students in English language. Journal of Research in Counseling Psychology 4(1): 84- 87.

Imogie AI 2002. Counselling for quality assurance in education. A keynote address delivered on the occasion of 26th Annual Conference of CASSON, University of Benin, Benin City, August, 2002.

Nzewunwah PN 1995. The Effects of Single Parenthood on the Academic Performance of Students. Unpublished M.Ed. Project. University of Lagos.

Sogbetun AA 1981. Teachers and Students Opinion about the Causes of Poor Academic Performance in Secondary Schools. Unpublished M.Ed. Project. Ibadan: University of Ibadan.

Wiseman S 1973. The educational obstacles race: Factors that hinder pupils' progress. Educational Research, 15(2): 87-93. 